\title{
Temnothorax affinis (Mayr) (Hymenoptera: Formicidae) - not extinct in Poland
}

\author{
Hanna BABIK, Wiesława CzEchOwsKA and Wojciech CZECHOwsKI
}

Museum and Institute of Zoology PAS, Laboratory of Social and Myrmecophilous Insects, Wilcza 64, 00-679Warszawa,Poland; e-mails: hbabik@miiz.waw.pl,wczechowska@miiz.waw.pl,wcz@miiz.waw.pl

\begin{abstract}
A new locality of Temnothorax affinis (Mayr), a Euro-Caucasian xerothermophilous dendrobiotic ant species rare in Central Europe, is reported from Poland; until recently it was regarded as probably extinct in Poland. Single workers were collected from an oak trunk of an old oak in the Cedynia Landscape Park (Pomeranian Lake District, north-western Poland). This locality is one of northernmost known sites of $T$. affinis.
\end{abstract}

Key words: ants, dendrobionts, fauna of Poland, Temnothorax affinis, threatened species

\section{INTRODUCTION}

Temnothorax affinis (Mayr) (formerly Leptothorax affinis Mayr) is a Euro-Caucasian xerothermophilous arboreal species, a stenotope of dry deciduous forests. It is distributed in Southern, Central and Eastern Europe, the Crimea and Caucasus. In Europe, the northern limit of its compact range corresponds approximately to the southern border of the mixed forest zone. The northernmost known locality of $T$. affinis is in south-eastern Sweden $\left(58^{\circ} \mathrm{N}\right)$, whereas in Central Europe this species does not go beyond $53^{\circ} \mathrm{N}$ (Radchenko 1995, Czechowski et al. 2002, Seifert 2007; see also Radchenko 2007).

T. affinis typically inhabits dry and warm light, mainly oak, forests, especially in habitats with a lime subsoil, nesting in dead parts of tree branches or, more rarely, at the foot of tree trunks, in fallen dry wood and empty plant stems. Colonies are monogynous and number up to ca. 200 workers (Seifert 2007).

\section{T. AFFINIS IN POLAND}

Until recently, T. affinis was known in Poland from two records made several dozen years ago, both from the southern part of the country. Kulmatycki (1920) was the first to find it (as Leptothorax tuberum affinis Mayr; giving no details of the founding) in the locality of Ujazd near Kraków (Kraków-Wieluń Upland). Subsequently Koehler (1951) reported a single male caught at the top of Trzy Korony Mt. (Pieniny Mts.). This latter report, in fact, cannot be regarded as proof of the occurrence of the species, as the winged sexual might have been blown in from afar. What is more, the identification itself cannot be considered reliable, as males of that group of species are practically indistinguishable and are not taken into consideration in modern keys for determination of ants (e.g. Czechowski et al. 2002, Radchenko et al. 2004, Seifert 2007). It is worth noting that neither Koehler's studies of the time nor all subsequent myrmecological surveys in the Pieniny Mts. in the 1970s (Czechowska 1976), 1980s (Woyciechowski 1985) and 1990s (Czechowski \& Czechowska 2000 and W. Czechowska, unpubl.) identified any workers of $T$. affinis there. It should be emphasised that the Pieniny Mts., owing to their geo-phytosociological properties (see e.g. Pancer-Kotejowa \& Zarzycki 1976), are a region where the probability of occurrence of the species under 
discussion seems to be especially high in Poland; the local fauna comprises exceptionally many xero- and thermophilous Southern European ant species, including those of the genus Temnothorax (Mayr) (see Czechowski et al. 2002).

Through lack of confirmation of its occurrence for more than 50 years, according to the principles established in the Polish Red Data Book of Animals (Głowaciński \& Nowacki 2004), T. affinis was regarded as probably extinct (EX?) in Poland (Czechowski et al. 2004). In previous issues of the Polish "red list", it was classified as vulnerable (V) (Pisarski et al. 1992) and critically endangered (CR) (Czechowski 2002).

However, T. affinis has just been found, almost at the same time, in two regions of Poland distant from each other. In May 2008, workers of this species were collected from trunks of different tree species in the locality of Strupina near Żmigród in Lower Silesia (Borowiec 2009). The locality is situated at the northern base of the Trzebnica Hills - a range of accumulated moraine hills of postglacial origin.

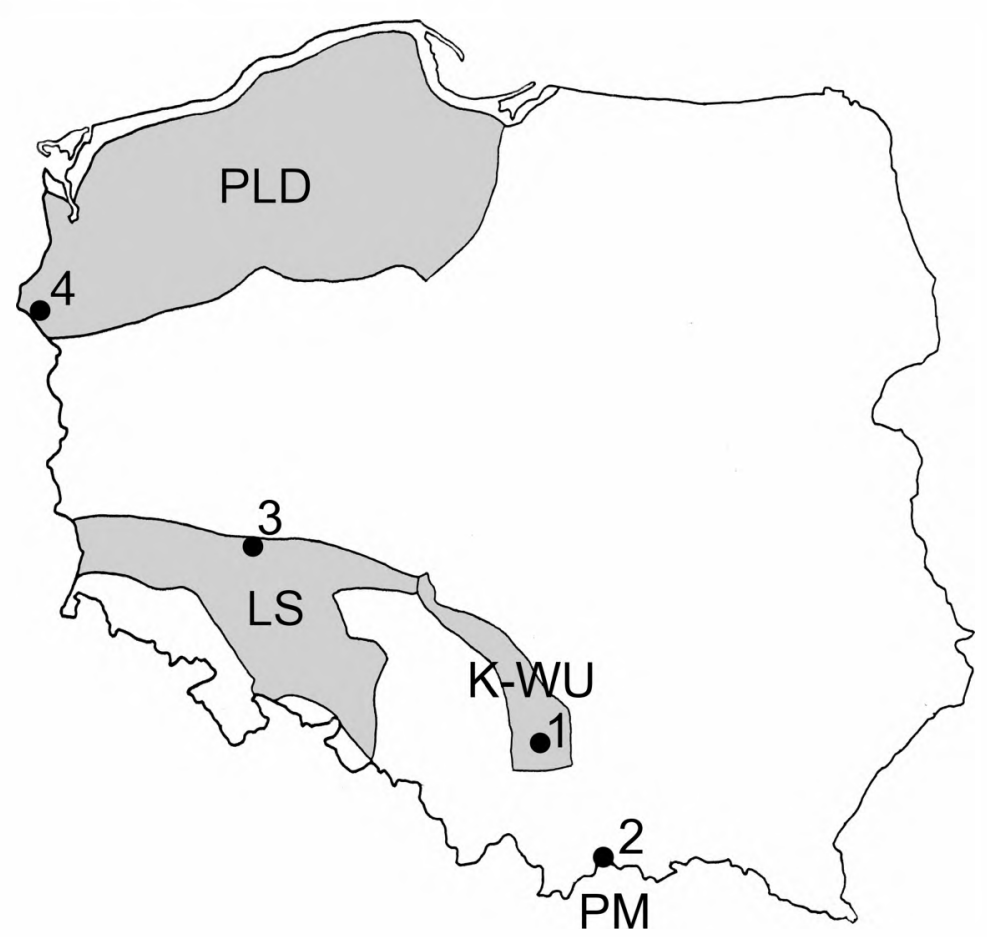

Fig. 1. Localities of $T$. affinis in Poland (related geographic regions are marked in grey): 1 - Ujazd near Kraków (Kulmatycki 1920), 2 - Trzy Korony Mt. (Koehler 1951), 3 - Strupina near Żmigród (Borowiec 2009), 4 - Stare Łysogórki near Cedynia (Cedynia Landscape Park; new locality) (K-WU - Kraków-Wieluń Upland, PM - Pieniny Mts., LS - Lower Silesia, PLD - Pomeranian Lake District).

On $1^{\text {st }}$ July, 2008, a team of the Museum and Institute of Zoology PAS found T. affinis in

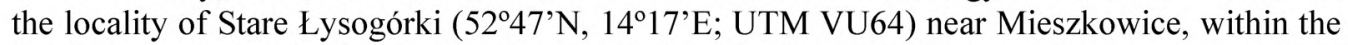
Cedynia Landscape Park in the Valley of the Lower Oder (Pomeranian Lake District) - one of the main sites of xerothermal vegetation in Poland (see e.g. Barańska \& Żmihorski 2007). Five workers were collected from a trunk of the relatively young (of several score years) oak, growing amongst a group of the scattered, mainly much older oaks [Quercus petraea 
(Mattuschka) Liebl.. and Q. robur L.] on the edge of a pine-oak forest. This site is not only the northernmost locality of $T$. affinis in Poland (Fig. 1), but also one of its northernmost localities in Central Europe (see Seifert 2007). For more reports of rare ant species in the Cedynia Landscape Park see Włodarczyk \& Barańska (2007).

In the light of these two recent findings, the conservation status of $T$. affinis in Poland, as a species presumably extinct in the country, certainly has to be revised. However, it still remains extremely rare and ought to be considered critically endangered (CR).

\section{ACKNOWLEDGEMENTS}

The authors thank Michał Żmihorski for his guidance in the field, and two referees, Vera Antonova and Sergey Belokobylskij, for reviewing the manuscript. This paper has been prepared as part of a research project sponsored by the Ministry of Science and Higher Education, Warsaw - Grant No. N303 012 31/0604.

\section{REFERENCES}

BARAŃSKA K. \& ŻMHHORSKI M. 2007. Stanowiska rzadkich gatunków roślin muraw kserotermicznych w Cedyńskim Parku Krajobrazowym (NW Polska). Badania Fizjograficzne nad Polską Zachodnią 56: 163-172.

BoroweC M. L. 2009. Nowe dane o rozmieszezeniu mrówek (Hymenoptera: Formicidae) plemienia Formicoxenini w Polsce. Wiadomości Entomologiczne (in press).

CzECHowska W. 1976. Myrmekofauna Pienińskiego Parku Narodowego (Hymenoptera, Formicidae). Fragmenta Faunistica 21: 115-144.

CzEchowsKi W. 2002. Formicidae. Mrówki. In: Glowacinski Z. (ed.). Czerwona Lista Zwierząt Ginących i Zagrożonych w Polsce, pp. 62-65. Instytut Ochrony Przyrody PAN, Kraków.

CZECHOWSKI W. \& CZECHOWSKA W. 2000. Epimyrma ravouxi (André, 1896) (Hymenoptera, Formicidae) in the Pieniny Mts - notes on its occurrence and biology. Fragmenta Faunistica 43: 29-33.

CZECHOWSKI W., CZECHOWSKA W. \& RADCHENKO A. 2004. Leptothorax affinis Mayr, 1855. In: GeowACniski Z. \& NowACKI J. (eds). Polska Czerwona Księga Zwierząt. Bezkręgowce, pp. 191-192. Instytut Ochrony Przyrody PAN, Kraków, Akademia Rolnicza im. A. Cieszkowskiego, Poznań.

CzECHOWsKi W., RADCHENKO A. \& CZECHOWsKa W. 2002. The Ants (Hymenoptera, Formicidae) of Poland. Museum and Institute of Zoology PAS, Warszawa, $200 \mathrm{pp}$.

GEoWACTŃski Z. \& NowACKI J. (eds.). 2004. Polska Czerwona Księga Zwierząt. Bezkręgowce. Instytut Ochrony Przyrody PAN, Kraków, Akademia Rolnicza im. A. Cieszkowskiego, Poznan, 448 pp.

KOEHLER W. 1951. Fauna Mrówek Pienińskiego Parku Narodowego. Państwowe Wydawnictwo Rolnicze i Leśne, Warszawa, $55 \mathrm{pp}$.

KuLMATYCKi W. 1920. Mrówki niektórych okolic Małopolski. Sprawozdanie Komisji Fizjograficznej 53/54: 157-172.

PANCER-KOTEJOWA E., ZARZYCKI K. 1976. Zarys fizjografii i stosunków geobotanicznych Pienin oraz charakterystyka wybranych biotopów. Fragmenta Faunistica 21: 21-49.

Pisarski B., Huflejt T., GarbarczyK H., GŁogowski S., KERYch E., Marczak P., SAwontewicz J. \& SkibIísKa E. 1992. Błonkówki. Hymenoptera. In: GŁowACńssKi Z (ed.). Czerwona Lista Zwierząt Ginących i Zagrożonych w Polsce, pp. 43-48. Zakład Ochrony Przyrody i Zasobów Naturalnych PAN, Kraków.

RADCHENKo A. G. 1995. Obzor murav'ev roda Leptothorax (Hymenoptera, Formicidae) Centralnoï i Vostochnoï Palearktiki. Soobshchenie 2. Gruppy tuberum, corticalis, affinis, clypeatus i singularis. Vestnik Zoologii 2/3: 14-21.

RADCHENKO A. 2007. Fauna Europaea: Formicidae. In: NoYES J. (ed.). Fauna Europaea: Hymenoptera: Apocrita. Fauna Europaea version 1.3., http://www.faunaeur.org

RADCHENKO A., CzECHOWSKA W. \& CZECHOWSKI W. 2004. Mrówki - Formicidae. Klucze do Oznaczania Owadów Polski, XXIV, 63. Polskie Towarzystwo Entomologiczne, Toruń, 138 pp.

SEIFERT B. 2007. Die Ameisen Mittel- und Nordeuropas. Lutra-Verlags- und Vertriebsgesellschaft, Görlitz, 368 pp.

WLODARCZYK T. \& BARAŃSKA K. 2007. Rzadkie gatunki mrówek występujące na murawach kserotermicznych Cedyńskiego Parku Krajobrazowego. Przegląd Przyrodniczy 18: 101-106.

WoYcIechowsKi M. 1985. Mrówki (Hymenoptera, Formicidae) Małych Pienin - Karpaty. Acta Zoologica Cracoviensia 28: 283-296. 


\section{STRESZCZENIF}

\section{[Temnothorax affinis (Mayr) (Hymenoptera: Formicidae) - nadal obecny w Polsce]}

Praca informuje o wykryciu nowego stanowiska Temnothorax affinis (Mayr) kserotermofilnego arborealnego gatunku euro-kaukaskiego, do niedawna uważanego za prawdopodobnie zanikly w Polsce (Polska Czerwona Księga Zwierząt, 2004). Robotnice T. affinis znaleziono na pniu dębu w Cedyńskim Parku Krajobrazowym (Dolina Dolnej Odry; Pojezierze Pomorskie). Stanowisko to leży blisko pólnocnej granicy zasięgu gatunku w Europie Środkowej. Nieco wcześniej (pierwszy raz po kilkudziesięcioletniej przerwie od poprzedniego stwierdzenia w Polsce) T. affinis zostal znaleziony na Śląsku Dolnym (Borowiec 2009).

Accepted: 4 May 2009 